\title{
A MODEL FOR THE IMPORTANCE OF LARGE ARBORESCENT PALMS IN THE DYNAMICS OF SEASONALLY-DRY AMAZONIAN FORESTS
}

\author{
Rodolfo Salm ${ }^{1}$, Euphly Jalles-Filho² \& Cynthia Schuck-Paim ${ }^{3}$ \\ Biota Neotropica v3 (n1) - http://www.biotaneotropica.org.br/v5n2/pt/abstract?article+BN02705022005 \\ Date Received 04/13/2005 \\ Revised 08/08/2005 \\ Accepted 09/12/2005

\begin{abstract}
${ }^{1}$ School of Environmental Sciences, University of East Anglia, Norwich, Norfolk NR4 7TJ, England. Universidade Federal de São Carlos, Programa de Pós-graduação em Ecologia e Recursos Naturais, Rododovia Washington Luís, km 235, Monjolinho. CEP 13565-905, São Carlos, SP, Brazil. e-mail: R.Salm@uea.ac.uk ${ }^{2}$ University of São Paulo, Department of Physiology (IB), Rua do Matão, Travessa 14, 05508-030, São Paulo, SP, Brazil e-mail: ejalles@terra.com.br

${ }^{3}$ University of São Paulo, Department of Experimental Psychology (IP), Av. Prof. Mello Moraes 1721, 05508-030, São

Paulo, SP, Brazile-mail: c.schuck@sciencenat.com
\end{abstract}

\begin{abstract}
In this study we propose a model that represents the importance of large arborescent palms in the dynamics of seasonally-dry Amazonian forests. Specifically, the model is aimed at guiding the investigation of the role of large arborescent palms on forest regeneration and succession. Following disturbance, the high level of luminosity reaching recently formed forest gaps favors the quick proliferation of shade-intolerant lianas that, by casting shade on the crowns of mature forest trees and increasing tree-fall probability, suppress forest succession. Due to their columnar architecture palm trees are, however, not severely affected by vines. As the palms grow, the canopy at the gaps becomes gradually higher and denser, progressively obstructing the passage of light, thus hindering the growth of shade-intolerant lianas and enabling late-successional tree development and forest regeneration. Owing to the long time associated with forest regeneration, the model cannot be tested directly, but aspects of it were examined with field data collected at an Attalea maripa-rich secondary forest patch within a matrix of well-preserved seasonally-dry forest in the Southeastern Amazon. The results indicate that (1) forest disturbance is important for the recruitment of large arborescent palms species, (2) these palms can grow rapidly after an event of disturbance, restoring forest canopy height and density, and (3) secondary forest dominated by palm trees species may be floristically similar to nearby undisturbed forests, supporting the hypothesis that the former has undergone regeneration, as purported in the model.
\end{abstract}

Key words: Amazon, Attalea maripa, forest dynamics, palm trees, regeneration.

\section{Resumo}

Neste estudo propomos um modelo que representa a importância de palmeiras arborescentes de grande porte na dinâmica das florestas amazônicas sazonalmente secas. Especificamente, o modelo visa guiar a investigação do papel destas palmeiras na regeneração da floresta. Após um evento de perturbação, a alta luminosidade das clareiras recentes favorece a rápida proliferação de lianas dependentes de insolação que, sombreando as copas das árvores e aumentando sua probabilidade de queda, tendem a interromper o processo de sucessão. Devido a sua arquitetura colunar, as palmeiras arborescentes, no entanto, não são severamente afetadas por lianas. À medida que estas palmeiras crescem, o dossel das clareiras se torna gradualmente mais alto e denso, limitando desta forma o crescimento das lianas e permitindo o desenvolvimento das árvores de estádios sucessionais tardios e, consequentemente, a regeneração da floresta. Devido ao longo período associado à regeneração da floresta o modelo não pode ser testado diretamente, mas aspectos deste foram examinados com dados de campo coletados em uma mancha de floresta secundária rica em Attalea maripa em uma matriz de florestas primárias bem preservadas no sudeste da Amazônia. Os resultados revelam que (1) eventos de perturbação florestal são importantes para o recrutamento das palmeiras arborescentes de grande porte, (2) estas palmeiras podem crescer rapidamente depois de eventos de perturbação, restaurando a altura e a densidade do dossel, e (3) florestas secundárias dominadas por espécies de palmeiras podem ser floristicamente semelhantes a florestas primárias adjacentes, apoiando a hipótese de que as primeiras avançam na regeneração, como previsto pelo modelo.

Palavras-chave: Amazônia, Attalea maripa, dinâmica florestal, palmeiras arborescentes, regeneração.

http://www.biotaneotropica.org.br 


\section{Introduction}

The understanding of succession processes in natural communities as well as their effects upon community stability and organization was among the major concerns of early ecologists (Cowles 1899). Initially, succession was described by a relatively rigid sequence of species successively invading a site (Clements 1916), a notion subsequently expanded to include predictable changes in characteristics of forest structure other than species composition, such as biomass, productivity, diversity and niche breath (Odum 1969). Although in these studies ecosystems were viewed as highly predictable and organized systems, objections to this concept arose early, reaching a critical point in the early seventies (Connell 1972, Drury \& Nisbet 1973) due to a lack of clearly defined and testable hypotheses about the mechanisms underlying succession events and relative scarcity of direct evidence of late succession stages (Connell \& Slatyer 1977).

To contribute to this matter Connell \& Slatyer (1977) described three models to explain the succession process after an event of disturbance: the facilitation model, the tolerance model and the inhibition model. All models purport that certain species can become established before others due to the presence of "colonizing" characteristics such as rapid growth and a high level of investment on reproduction. The three models differ, however, in the mechanisms whereby new species colonize the area later in the succession cycle: the facilitation model assumes that only certain “early succession” species are able to colonize the site immediately following perturbation, modifying the environment so that it is more suitable for later succession species to invade and grow to maturity - the original conception of succession (Clements 1916). The other two models, conversely, assume that any arriving species, including those which usually appear later in the succession process, can colonize a disturbed site. The tolerance model assumes that the modification brought about by earlier colonists neither increases nor reduces the recruitment rate and probability of growth to maturity of later colonists. Finally, the inhibition model proposes that once earlier colonists secure space or other resources, succession is suppressed.

Seasonally-dry forests, consisting of an assemblage of ecologically diverse vegetation formations and generally characterized by high discontinuity of their canopy, variable level of deciduousness and strong spatial variation in floristic macromosaics, cover a substantial area of the Amazon basin. These forests are distributed mostly along rainfall gradients defining the limits between the Amazonian forest and external dryer vegetation biomes (Pires 1984, Gentry 1988, Daly \& Prance 1989), an area now often referred to as 'Deforestation Arc of Amazonia' (Fearnside 1993, Fearnside 1995). In this study we investigate the role played by large arborescent palms in the dynamics of seasonally-dry Amazonian forests. Specifically, we propose a simplified model of the system, in which the role of palm trees in the dynamics of forest succession and regeneration is explored (Figure 1 ).

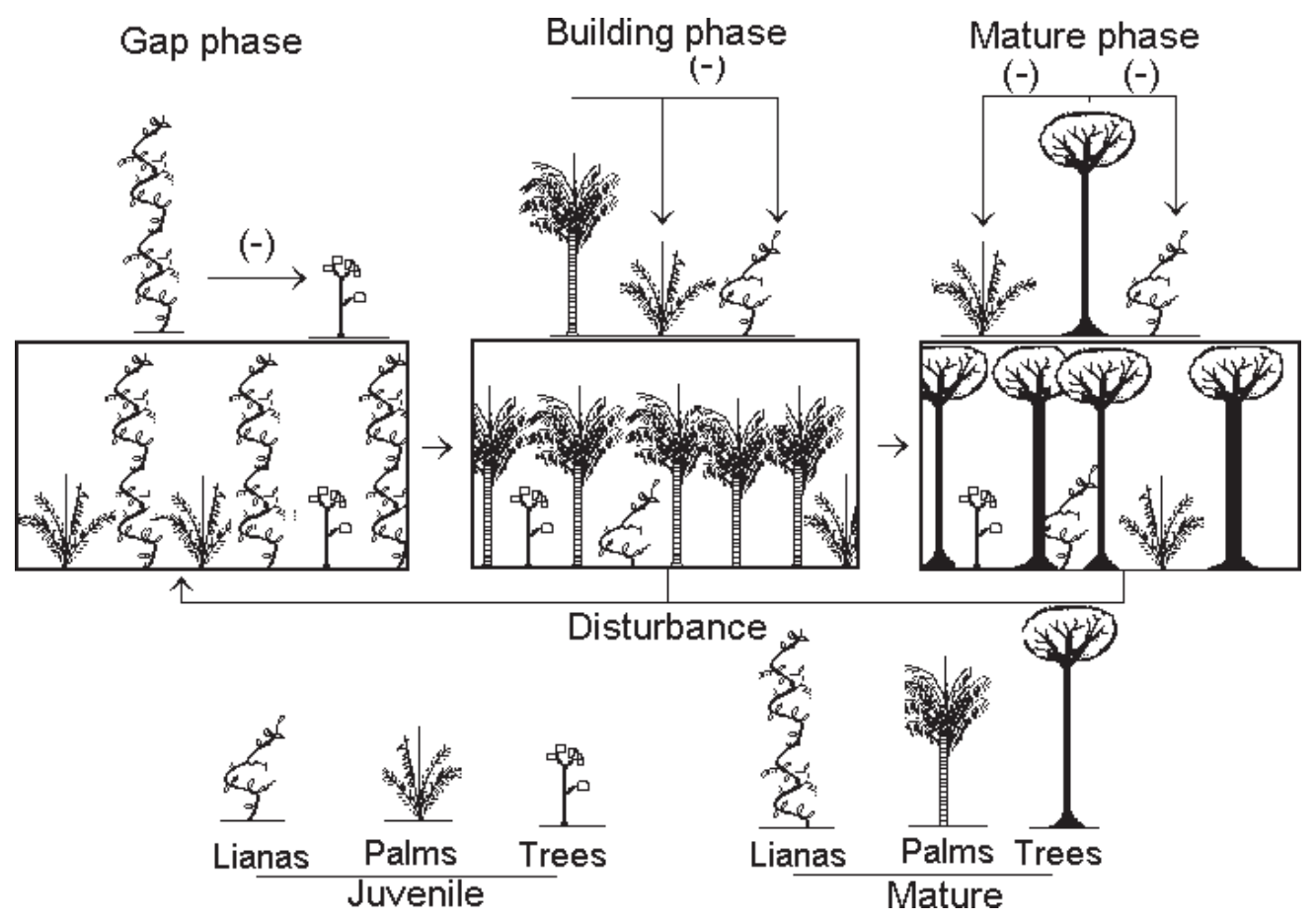

Figure1. Pictorial model of the importance of large arborescent palm on the regeneration dynamics of seasonally dry Amazonian forests. The negative sign indicates an inhibition effect, whereby the growth of one functional plant group is inhibited, e.g. by another group (for instance, in the gap phase, the presence of lianas inhibit the growth of trees). For a definition of the plant groups and regeneration phases, see the text. 
The influence of large arborescent palms in the dynamics of succession proposed here, incorporates elements of the three models of Connell \& Slatyer (1977), as we shall explain as follows. Before proceeding, some explanations are however necessary. Our model considers three functional groups of plants: "shade-intolerant lianas", "large arborescent palms” and "mature-forest trees”. Although dissimilar in many aspects, one difference of special relevance to the present discussion is the distinct response of the three mentioned groups of plants to light: mature-forest trees have highest survival likelihood under low light intensity, shade-intolerant lianas show the opposite response, having the lowest capacity to survive light shortage (and highest growth rate at maximal light intensity), with large arborescent palms being intermediate.

Additionally, forest succession is heuristically partitioned here into three phases: a "gap phase", a "building phase" and a "mature phase" (Aubréville 1938). The gapmosaic dynamics, first proposed by Aubréville, have become a fundamental concept in tropical forest ecology (Richards 1996). The idea is currently widely used in analysis of tree species distribution (Sheil \& Ducey 2002) and the assessment of the impact of economic activities upon tropical forests (Fredericksen \& Putz 2003). The first phase corresponds to that immediately following an event of disturbance, which leads as a by-product to the opening of clearings in the forest, hence the terminology 'gap'. Regeneration leads to maturity, namely the reestablishment of canopy height and density and the re-colonization of the area by species of trees typical of mature forests. Once at the mature phase, only a new disturbance event can bring the forest back to the gap phase.

The effect of large arborescent palms on forest regeneration can be then understood by considering the following dynamics. At the mature phase, the canopy is composed mainly by the group of mature-forest trees, being dense to a point that the reduced light conditions below it prevents palm (Chazdon 1986, Kahn 1986, Tomlinson 1990, Kahn \& de Granville 1992) and liana growth (Schnitzer et al. 2000, Alvira et al. 2004). Such an equilibrium can be broken by an event of disturbance, which by opening clearings in the forest enables solar radiation to reach the soil level with a higher intensity. Shade-intolerant lianas are then able to proliferate almost immediately, becoming dominant in this gap phase (Radam 1974). Although lacking self-support capacity, lianas can climb the trees by using their structure as support, thus severely suppressing tree growth and survival (see e.g. Radam 1974 and Richards 1996 for examples in seasonally-dry forests). Additionally, they cast shade on tree crowns and increase tree-fall probability (Schnitzer et al. 2000, Alvira et al. 2004), thus suppressing forest succession. Due to their columnar architecture palm trees are, however, not severely affected by vines (Richards 1996). As the palm trees grow, the canopy at the gaps becomes gradually higher and denser, progressively obstructing the passage of light, thus hindering the growth of shade-intolerant lianas and consequently favoring tree development and forest regeneration. We also propose that palm trees are selflimiting because, as other early successional species, the development of juveniles is hampered by the shadow produced by adult palms. With growth of mature forest trees and palm senescence, the gap phase progresses to maturity, and forest structure stabilizes again.

Similarly to Connell \& Slatyer's facilitation model (1977), the model just described above is fundamentally facilitative, as it states that once a disturbance opens a relatively large space releasing resources (light and space), large arborescent palms are among the early succession species to become established, modifying the environment so that it becomes less suitable for the subsequent recruitment of early succession species, but more suitable for the recruitment of late succession species. It also incorporates a component of "tolerance" when it assumes that shade-intolerant lianas are replaced by palm trees which, in turn, are replaced by mature-forest trees, so that the sequence of species is determined, not solely but fundamentally, by lifehistory characteristics that enable survival and growth despite the shade cast by early succession species. Inhibition is also considered in our model, since shade-intolerant lianas limit mature-forest trees and, as long as they persist, continue to exclude or suppress subsequent colonists of the mature forest.

We do not propose that should large arborescent palms be removed from the ecosystem, regeneration would not proceed on the seasonally-dry Amazonian forests. The balance between forest building and regression depends on a wide range of factors affecting tree growth and survival. In these highly seasonal forests, both drought and flooding contribute for disturbance, thereby explaining the high frequency of open forests areas with liana-rich formations (Radam 1974). Due to their columnar architecture, which hinders the spread of lianas, palm trees are however able to shift this balance in favor of denser vegetations.

It is important to highlight that the influence of palms on forest succession as proposed here is specifically attributed to the large arborescent forms of palms. Neotropical palms range widely from shade tolerant to needing high levels of light (Svenning 2001). Because the stem of palms is entirely primary, with no addition of secondary vascular or thickening tissues, the establishment phase imposes considerable limitation on the overall habit of the plant (Tomlinson 1990). Palm trees compensate for the increasing mechanical support requirements during height growth by a combination of initial development of a stem that has sufficient diameter, sustained cell expansion and increase of stiffness and strength of the stem tissue with age. In some cases, there is also cell division within the stem (Rich 1987). Due to the growth of their large stem, arborescent palms 
become increasingly light-demanding with increasing size (de Granville 1992) and generally depend on large gaps for recruitment to the adult stage (Kahn 1986), whereas small palms are widespread at the understorey of tropical forests, even under the energetically restricting conditions of dense shade cast by the canopy (Chazdon 1986).

Indeed, ecologists soon related the developmental constraints imposed by the establishment phase of large arborescent palms to the general rarity of palm trees in areas of dense forest with closed canopy, when compared to open forests (Kahn 1986, de Granville 1992, Kahn \& de Granville 1992). While most species of large arborescent palms are generally rare in pristine, well-drained areas, they often dominate secondary forests in the Amazon (Spruce 1871, Kahn \& Castro 1985, Kahn et al. 1988, Kahn \& de Granville 1992, Ballée 1988, 1989). An exception is the palm Iriartea deltoidea, remarkably abundant in western Amazonia (Pitman et al. 2001). This species does not seem to depend on large gaps for recruitment (Svenning 1999). Such an exception might be explained by the growth of stilt roots that give structural support to the development of a mature sized trunk aboveground (Uhl \& Dransfield 1987), and the possibility of these palms to grow under dense canopy (Terborgh \& Davenport 2001).

For example, large areas dominated by palm trees in the Brazilian State of Maranhão are related to a ancient colonization frontier at this region (Kahn \& de Granville 1992), and forest patches at the State of Pará were associated through archaeological evidence to abandoned Indian villages (Ballée 1988, 1989). Palm trees are also often dominant in cleared areas around roads across the seasonally dry Amazonian forests. It is important to take into account that, although many large arborescent palms have ecological requirements as described by the model, this is not true for all (Svenning 1999, Araus \& Hogan 1994), as described above in relation to the silt-palm I. deltoidea (Svenning 1999, Uhl \& Dransfield 1987, Terborgh \& Davenport 2001).

Also of importance is the observation that the proposed model is, in its present form, restricted to seasonallydry Amazonian forests, since the dynamics of regeneration is likely to follow different routes, involving mainly early successional dicotyledonous trees, under conditions other than those found in these biomes. In the seasonally-dry Amazonian forests, the alternating annual periods of strong rainfall and drought create a high level of natural disturbance, suitable for the growth of gigantic trees like mahoganies (Swietenia macrophylla) and Brazil-nuts trees (Bertholletia excelsa), which create enormous gaps upon their deaths further increasing disturbance, thus establishing the ideal circumstances for the recruitment and growth of large arborescent palms (Kahn 1986). But regeneration not necessarily involving palms as ecologically important colonizing-trees seem to prevail wetter areas elsewhere in the Amazon. In Central Amazon, for example, secondary for- ests are colonized by pioneer dicotyledonous species of the genus Cecropia or Vismia (Mesquita et al. 2001). Palm trees indeed appear to be of much less important for regeneration both in the rainier areas of the Amazon and on the Atlantic forest. One reason behind the difference in the influence of palm trees on regeneration among ecosystems might be associated to the relative competitive advantage of shade-intolerant lianas over mature forest trees in seasonally dry areas, due to the vines' ability to produce deeper roots than trees with the energy that these climbers save by not producing a self-sustained stem. Such deep roots allow the vines to reach the phreatic water for a longer period at the dry-season - an advantage that is relatively less important in wetter forests (Nepstad et al. 1994).

\section{Materials and methods}

Some aspects of the model are examined with field data collected at an Attalea maripa-rich secondary forest patch within a matrix of well-preserved seasonally-dry forest in the Southeastern Amazon. To this end, we studied a patch of secondary forests where palm trees were abundant, in a matrix of primary forests, a few hundred meters from the Pinkaití research station (7 46’18"S; 515 57’42"W), at the Kayapó Indigenous Lands, South-eastern Amazon, Brazil. A palm grove that, according to the Kayapó indigenous population at the area, was cleared for the plantation of subsistence crops and subsequently abandoned in the first half of the last century, was adjacent to a large isolated hillside, the mirante, which provided a panoramic view of the study area. The study area was formed by a forest of several hectares largely dominated by palm trees, being adjacent to a denser forest, where few palm trees can be seen. In a 16 ha grid system, established at the limit between these areas, adult palms were exhaustively searched and 569 A. maripa palms were mapped. Within this grid, and at a surrounding undisturbed forest, studies were conducted on tree species diversity (Salm 2004a), palm growth (Salm 2004b) and the importance of forest disturbance for the recruitment of large arborescent palms (Salm 2005).

\section{Results and discussion}

The results of these studies show that the large arborescent palm $A$. maripa are generally rare at undisturbed areas of the Pinkaití (2 palms ha-1), but abundant in naturally disturbed (12 palms ha-1) (Salm 2005) and dominant at a patch of secondary forests within the study site (53 palms ha-1) (Salm 2004a). These findings support the proposed notion of large arborescent palms as light demanding successional species that depend on large events of disturbance to become ecologically dominant - a view that, although disputed (Svenning 1999), is largely accepted (Kahn 1986, de Granville 1992, Kahn \& de Granville 1992), and essential to our model. 
The relatively fast rate of palm growth in height assumed in the model, which quickly leads to the development of a relatively dense canopy, will keep the sun from directly reaching the soil and therefore limit the growth of shade-intolerant lianas. Supporting this assumption, growth rate estimates showed that, once the palm's stem of adult diameter is developed, a palm-dominated canopy could be formed within a decade (Salm 2004b). This finding also highlights the potential importance of large arborescent palms as facilitative "tools" in programs of regeneration of deforested areas within the largely destroyed and endangered (Zimmerman et al. 2001) seasonally-dry Amazonian forests.

Additionally, the studied patch of secondary forest seems to be in an advanced stage of regeneration, having senescent palm populations (Salm 2004b) and floristically resembling the pristine areas of the Pinkaití Research Station (Salm 2004a). The successional nature of the palm grove is in fact evident on the structure of this forest patch. Its basal area is extremely low $\left(15 \mathrm{~m}^{2} \cdot \mathrm{ha}^{-1}\right)$, significantly lower than that of the adjacent pristine forest (Salm 2004a). Such basal area is even lower than the limits $\left(18-24 \mathrm{~m}^{2} . \mathrm{ha}^{-1}\right)$ considered for liana forests (Pires \& Prance 1985). The average height of the palm grove forest, on the other hand, is not significantly different from that of the adjacent forest (Salm 2004a). These observations support the model's proposed role for arborescent palms on the regeneration of ecosystem structure, given its reconstituting role of canopy height and density.

Taken together, these results support the proposed role or arborescent palms on the regeneration of seasonally dry Amazonian forests. A final remark is however necessary. Despite its importance in the model, the negative effects of lianas on the growth of mature forest trees as well as on palms were not directly studied here due to the practical difficulties to measure vine's biomass and, perhaps most importantly, the limitations associated to the temporal scale needed for such an investigation. Still, their suppressive effects on mature forest trees, by shading their crowns and increasing tree fall probability, is recognized by the Kayapó Indians (who cut the vines that climb useful tree species) and well-known in the forestry literature (Alvira et al. 2004, Bongers et al. 2002). In Central America (Barro Colorado Island), vines dominate gap-phase regeneration and seem to inhibit non-pioneer tree survival (Schnitzer et al. 2000) but are significantly more abundant in younger than in older forests (Dewalt et al. 2000).

In conclusion, our model provides the basis for new lines of investigation that will allow the ecology of palm trees to be better understood within the context of Amazonian forests. Field investigation in other regions, aided by the use of high-definition satellite imagery enabling the assessment of forest structure over large areas, should foster the development of the model together with its ability to make quantitative predictions. Nevertheless, as it stands, it highlights the potential role of palms as tools for envi- ronmental reconstitution in a likely future of large-scale deforestation in the Amazon. It is our hope that it contributes for the development of further studies applied to the conservation of the highly threatened seasonally-dry forests of the Amazon, and to the sustainable exploitation and management of these ecologically important and economically valuable palm species.

\section{References}

ALVIRA, D, PUTZ, F.E. \& FREDERICKSEN T.S. 2004. Liana loads and post-logging liana densities after liana cutting in a lowland forest in Bolivia. For. Ecol. Manage. 190: 73-86.

ARAUS, J. L. \& HOGAN, K. P. 1994. Leaf structure and patterns of photoinhibition in two Neotropical palms in clearings and forest understory during the dry season. Am. J. Bot. 81: 726-738.

AUBREVILLE, A. 1938. La foret coloniale: les forets de l'Afrique occidentale francaise. An. Acad. Sci. Colon. Paris, 9: 1-245.

BALLÉE, W. 1988. Indigenous adaptation to amazonian palm forests. Principes 32: 47-54.

BALLÉE, W. 1989. The Culture of Amazonian Forests. Adv. Econ. Bot. 7: 1-21.

BONGERS, F., SCHNITZER, S.A. \& TRAORE, D. 2002. The importance of lianas and consequences for forest management in West Africa. BioTerre, Special edition: 59 - 70.

CHAZDON, R.L. 1986. Light variation and carbon gain in rainforest understory palm. J. Ecol. 74: 995-1012.

CLEMENTS F.E. 1916. Plant succession: an analysis of the development of vegetation. Washington Publ, Washington.

CONNELL, J.H. 1972. Community interactions on marine rocky intertidal shores. Ann. Rev. Ecol. Syst. 3: 169-192.

CONNELL, J.H. \& SLATYER, R.O. 1977. Mechanisms of succession in natural communities and their role in community stability and organization. Am. Nat. 111: 119-1144.

COWLES, H.C. 1899. The ecological relations of the vegetation on the sand dunes of Lake Michigan. Bot. Gaz. 27:97-117.

DALY, D. C. \& PRANCE, G. T. 1989. Brazilian Amazon. In Floristic inventory of tropical countries (D. G. Campbell \& H. D. Hammond eds.) New York Botanical Garden, New York, p. 401-426.

DE GRANVILLE, J. 1992. Life Forms and Growth Strategies of Guianan Palms as Related to their Ecology. Bull. I. Fr. Étud. And. 21: 533-548.

DEWALT, S.J., STEFAN, A.C., SCHNiTZER, A. \& DENSLOW, J.S. 2000. Density and diversity of lianas along a chronosequence in a central Panamanian lowland forest. J. Trop. Ecol. 16:1-19. 
DRURY, W.H. \& NISBET, I.C.T. 1973. Succession. J. Arnold Arboretum 54: 331-368.

FEARNSIDE, P.M. 1993. Deforestation in Brazilian Amazonia: the effect of population and land tenure. Ambio 22: 537-545.

FEARNSIDE, P.M. 1995. Potential Impacts of ClimaticChange on Natural Forests and Forestry in Brazilian Amazonia. For. Ecol. Manag. 78: 51-70.

FREDERICKSEN, T. S, PUTZ, F. E. 2003. Silvicultural intensification for tropical forest conservation. Biod. Conserv. 12: $1445-1453$.

GENTRY, A.H. 1988. Changes in plant community diversity and floristic composition on environmental and geographical gradients. Ann. Missouri Bot. Gard. 75: 1-34.

KAHN, F. \& CASTRO, A. 1985. The palm community in a forest of central Amazonia, Brazil. Biotropica 20: 266-269.

KAHN, F. 1986. Life forms of Amazonian palms in relation to forest structure and dynamics. Biotropica 18: 214-218.

KAHN, F., K. MEJIA, \& CASTRO, A. 1988. Species richness and density of palms in terra firme forests of Amazonia. Biotropica 20: 266-269.

KAHN, F. \& GRANVILLE, J. 1992. Palms in forest Ecosystems of Amazonia. Springer Verlag, Heidelberg.

MESQUITA, R.C.G., ICKES, K., GANADE, G. \& WILLIAMSON, G. B. 2001. Alternative successional pathways in the Amazon basin. J. Ecol. 89: 528-537.

NEPSTAD, D.C., DE CARVALHO, C.R. \& VIEIRA, S. 1994. The role of deep roots in the hydrological and carbon cycles of Amazonian forests and pastures. Nature 372: 666.

ODUM, E.P. 1969. The strategy of ecossistem development Science 164: 262-270.

PIRES, J.M. 1984. The Amazonian forest. In The Amazon: limnology and landscape ecology of a mighty tropical river and its basin (H. Sioli, ed.). Dr. W. Junk Publishers, Dordrecht, p. 581-601.

PIRES, J.M. \& PRANCE, G.T. 1985. Vegetation types of the Brazilian Amazonia. Amazonia. G. T. Prance and T. E. Lovejoy. Oxford, Pergamon Press.

PITMAN, N.C.A., TERBORGH, J.W., SILMAN, M.R., NÚNEZ V.P., NEILL, D.A., CERÓN, C.E., PALACIOS, W.A., \& AULESTIA, M. 2001. Dominance and distribution of tree species in upper Amazonian terra firme forests. Ecology, 82: 2101-2117.

RADAM 1974. Projeto RadamBrasil. Folha SB22 Araguaia e parte da folha SC 22 Tocantins. Instituto Brasileiro de Geografia e Estatística, Rio de Janeiro.

RICH, P.M. 1987. Mechanical structure of the stem of arborescent palms. Bot. Gaz. 148: 42-50.

RICHARDS, P.W. 1996. The tropical rain forest. Cambridge University Press, Cambridge.
SALM, R. 2004a. Tree species diversity in a seasonally-dry forest: the case of the Pinkaití site, in the Kayapó Indigenous Area, Southeastern limits of the Amazon. Acta Amaz. 34: 435-443.

SALM, R. 2004b. Densidade do caule e crescimento de Attalea maripa e Astrocaryum aculeatum: implicações para a distribuição de palmeiras arborescentes na floresta Amazônica. Biota Neotrop. 4 (1): http:// ww w.biotaneotropica.org.br/v4n1/pt/ abstract?article+BN00104012004

SALM, R. 2005. The importance of forest disturbance for the recruitment of the large arborescent palm Attalea maripa in a seasonally-dry Amazonian forest. Biota Neotrop. 5:1. http://www.biotaneotropica.org.br/v5n1/pt/ abstract?article+BN00305012005

SHEIL, D. \& DUCEY, M. 2002. An extreme-value approach to detect clumping and an application to tropical forest gap-mosaic dynamics. J. Trop. Ecol. 18: 671-686.

SCHNITZER, S.A., DALLING, J.W. \& WALTER, P. 2000. The impact of lianas on tree regeneration in tropical forest canopy gaps: evidence for an alternative pathway of gap-phase regeneration. J. Ecol. 88: 655-666.

SPRUCE, R. 1871. Palmae Amazonicae. J. Linn. Soc. Bot. 11: 65-183.

SVENNING, J.C. 1999. Recruitment of tall arborescent palms in the Yasuni National Park, Amazonian Ecuador: are large treefall gaps important? J. Trop. Ecol. 15: 355-366.

SVENNING, J.C. 2001. Environmental heterogeneity, recruitment limitation and the mesoscale distribution of palms in a tropical montane rain forest (Maquipucuna, Ecuador). J. Trop. Ecol. 17: 97-113.

TERBORGH, J. \& DAVENPORT, L. 2001. Endogenous and exogenous control of leaf morphology in Iriartea deltoidea (Palmae). J. Trop. Ecol. 17:695-703.

TOMLINSON, P.B. 1990. The structural biology of palms. Clarendon Press, Oxford.

UHL, C. \& DRANSFIELD, J. 1987. Genera Palmarum. Allen Press, Kansas.

ZIMMERMAN, B., PERES, C.A., MALCOLM, J.R. \& TURNER, T. 2001. Conservation and Development Alliances with the Kayapó of South-eastern Amazonia, a Tropical Forest Indigenous People. Env. Conserv. 28: 10-22.

Title: A model for the importance of large arborescent palms in the dynamics of seasonally-dry Amazonian forests.

Authors: Rodolfo Salm, Euphly Jalles-Filho \& Cynthia Schuck-Paim

Biota Neotropica, Vol. 5 ( number 2): 2005

http://www.biotaneotropica.org.br/v5n2/pt/ abstract?article+BN02705022005

Date Received 04/13/2005 - Revised 08/08/2005

Accepted 09/12/2005

ISSN 1676-0611 